социально-экономического содержания у учащихся с нарушениями интеллектуального развития в рамках изучения курса «География Украины» (9 класс).

Ключевые слова: умственно отсталые учащиеся, сочиально-экономические знания, полнота знаний, осознанность, действенность знаний, констатирующий этап исследования

УДК 376.3

Ірина Чистякова

Сумський державний педагогічний університет імені А. С. Макаренка

ORCID ID 0000-0001-8645-510X

DOI 10.24139/2312-5993/2019.05/301-315

\title{
СТРУКТУРНО-ЛОГІЧНА МОДЕЛЬ ВИХОВАННЯ ДІТЕЙ ДОШКІЛЬНОГО ВІКУ 3 ОСОБЛИВИМИ ОСВІТНІМИ ПОТРЕБАМИ В СПЕЦІАЛЬНИХ ЗАКЛАДАХ ОСВІТИ
}

у статті представлено розроблену автором модель виховання дітей дошкільного віку із затримкою психічного розвитку в спечіальних закладах освіти, яка включає реалізацію послідовно структурованих компонентів (цільовий, теоретикометодологічний, змістово-процесуальний та очінно-результативний блоки), змістове наповнення яких уточнює інформачійний образ прочесу, що моделюється. Запропонована модель покликана забезпечити безперервність процесу виховання дошкільників із затримкою психічного розвитку в спеціальних закладах освіти. Доведено, що виховна робота з дітьми дошкільного віку $\epsilon$ обов'язковою складовою освітнього процесу в спеціальному закладі освіти. Цей вид педагогічної діяльності використовується для створення середовища, необхідного для всебічного розвитку дитини.

Ключові слова: виховання, вихованість, діти дошкільного віку, затримка психічного розвитку, спеціальний заклад освіти, модель виховання.

Постановка проблеми. Виховна робота з дітьми із затримкою психічного розвитку надзвичайно актуальна в сучасному світі, оскільки в даний час спостерігається збільшення числа дітей із проблемами в психічному розвитку, більшість із них відчувають труднощі в адаптації та соціалізації, у засвоєнні програми закладу дошкільної освіти (ЗДО). Одна з важливих проблем освіти сьогодні - розвиток нових підходів у виховній роботі з дітьми з особливими освітніми потребами (ООП). Увага до проблем виховної роботи з дітьми з ООП з боку держави, що проявляється в законодавчих актах, спрямованих на всебічну допомогу таким дітям, створення необхідних умов для постійного розвитку й удосконалення виховного процесу в закладі дошкільної освіти, а також здійснення закладом дошкільної освіти соціального замовлення батьків (законних представників) на виховання й навчання дітей з ООП, $є$ мотивацією до пошуку доцільних форм і методів виховної роботи з дітьми з ООП у закладі дошкільної освіти. 
Дитина з ООП, як і всі діти, у своєму розвитковві спрямована на освоєння соціального досвіду, соціалізацію, включення в життя суспільства. Однак шлях, який вона повинна пройти для цього, значно відрізняється від загальноприйнятого. Як показує практика, дітям із особливими освітніми потребами не підходить загальноосвітня програма закладу дошкільної освіти. Не можна не погодитися, що і вихователі, і спеціалісти закладу дошкільної освіти стикаються з великою кількістю проблем щодо організації освітнього процесу, у межах якого здійснюється виховна робота.

Відтак, на підставі всього вищесказаного можемо стверджувати, що доцільність розгляду питання виховання дітей дошкільного віку 3 особливими освітніми проблемами не викликає сумнівів та зумовлюється необхідністю розв'язання суперечності між необхідністю виховної роботи $з$ дітьми в ЗДО з урахуванням особливих освітніх потреб та недостатністю методичного забезпечення зазначеного процесу.

Як показують комплексні дослідження, більшу частину дітей, які зазнають труднощів у вихованні, складають діти із затримкою психічного розвитку, які за ступенем сформованості деяких психічних функцій не відповідають своєму вікові, а як би перебувають на більш ранніх стадіях розвитку. Відтак, зросла необхідність розробки питань виховання дітей дошкільного віку із ЗПР порівняно з дітьми, які нормально розвиваються. Збільшення числа таких дітей відзначається в усьому світі, тому проблема труднощів у вихованні стала однією з актуальних психолого-педагогічних проблем сьогодення.

Аналіз актуальних досліджень. В останні роки обговорення проблем та спеціальної школи характеризується посиленою увагою держави, учених до учнів, які відчувають стійкі труднощі у вихованні та в адаптації до соціального оточення. У центрі уваги науковців значне місце посідають проблеми організації процесу виховання дітей з особливими освітніми потребами. Питання ефективної організації процесу виховання дітей із порушеннями психофізичного розвитку стали предметом досліджень таких науковців, як А. Бєлкін, В. Бондар, М. Буфетов, О. Вержиховська, Л. Виготський, А. Висоцька, В. Воронкова, І. Дмитрієва,О. Дьячков, Г.Дульнєв, І. Єременко, М. Земцова, С. Зиков, О. Коган, М. Козленко, І. Колесник, В. Левицький, В. Липа, О. Ляшенко, В. Мачихіна, С. Миронова, В. Синьов, О.Хохліна та ін. Ученими визначено основні принципи, завдання, форми й методи виховання, виокремлено основні напрями виховної роботи (моральне, трудове, фізичне, естетичне та ін.), запропоновано рекомендації щодо організації роботи з дітьми тощо. 
Дидактичні та методичні засади спеціальної освіти розумово відсталих дошкільників вивчали Г.Блеч, І.Бобренко, А. Висоцька, І. Гладченко, Н. Макарчук, А. Міненко, С. Трикоз, О. Чеботарьова.

Отже, у теорії та практиці спеціальної педагогіки відчувається нестача необхідних напрацювань із проблеми виховання дітей дошкільного віку 3 особливими освітніми потребами, зокрема із затримкою психічного розвитку.

У зв'язку з цим у даній статті ми поставили за мету розробити структурно-логічну модель виховання дітей дошкільного віку з особливими освітніми потребами, зокрема із затримкою психічного розвитку, у спеціальних закладах освіти.

Методи дослідження. У даній статті для досягнення зазначеної мети використано такі методи, як: теоретичні (аналіз психологічної, педагогічної, методичної літератури за проблемою дослідження для виявлення сутності основоположних понять; порівняння, узагальнення й систематизація матеріалів для розробки моделі виховання дітей дошкільного віку 3 особливими освітніми потребами в спеціальних закладах дошкільної освіти).

Виклад основного матеріалу. У науковій літературі поширеним $\epsilon$ розуміння поняття «виховання» запропоноване О.Петровським та М.Ярошевським, які трактують означений термін як діяльність із метою передачі новим поколінням суспільно-історичного досвіду, планомірний і цілеспрямований вплив на свідомість і поведінку людини з метою формування відповідних установок, понять принципів, ціннісних орієнтацій, що забезпечує необхідні умови для їі розвитку, підготовки до суспільного життя та трудової діяльності (Петровський та Ярошевський, 1996).

На думку О. Вержиховської та І. Рудзевича, виховання передбачає «формування особистості» у двох аспектах:

1. 3 погляду психології, формування особистості як процес і результат iï розвитку, формування особистості, виявлення того, що $\epsilon$ наявне, експериментально виявлене, досліджене і що може бути в особистості, яка розвивається в умовах цілеспрямованого впливу. Як бачимо, психологічний підхід включає діагностичний.

2. Формування особистості як цілеспрямоване виховання особистості, яке виходить із потреб суспільства. 3 погляду педагогіки - це те, що $€$ і як повинно бути сформовано в особистості, щоб вона відповідала соціально зумовленим вимогам, які висуває до неї суспільство. Отже, педагогічний підхід включає цілеспрямований, систематичний вплив, спеціально організовану діяльність по формуванню особистості дитини (Вержиховська та Рудзевич, 2016). 
Переконані, що у виховному процесі відбувається розвиток загальнолюдських цінностей, які виступають результатами життєвої педагогіки, набутими кількома поколіннями народу.

у спеціальній освіті виховання розглядається як цілеспрямований організований процес педагогічної допомоги в соціалізації, соціокультурному включенні й соціальному адаптуванні людини 3 обмеженими можливостями життєдіяльності.

Погоджуємося з думкою Н. Назарової, яка констатує, що людина 3 обмеженими можливостями, як і всі інші люди, у своєму розвиткові спрямована на освоєння соціального досвіду, соціалізацію, включення в життя суспільства. Однак, фізичні та психічні вади змінюють розвиток зростаючої людини. Обмеження можливостей - це інтегральна зміна особистості в цілому. Тому для вирішення освітнього завдання такій людині необхідно не тільки особливим чином освоювати власні загальноосвітні програми, а й формувати й розвивати навички соціального адаптування:

- орієнтування в просторі й часі, самообслуговування й соціальнопобутова орієнтація, різні форми комунікації, свідома регуляція власної поведінки в суспільстві, фізична й соціальна мобільність;

- заповнення недоліків знань про навколишній світ, пов'язані 3 обмеженням можливостей;

- розвиток потребнісно-мотиваційної, емоційно-вольової сфер;

- формування й розвиток здібностей до максимально незалежного життя в суспільстві;

- вироблення активної та оптимістичної життєвої позиції (Назарова, 2009).

На основі аналізу наукової літератури з досліджуваної проблеми можемо стверджувати, що в спеціальній педагогіці виховання цілеспрямована соціальна взаємодія, змістом якої є спеціальна педагогічна допомога людині з обмеженими можливостями життєдіяльності в ї̈ розвитку, соціалізації, освоєнні нею діючих соціокультурних норм і цінностей, у соціокультурному включенні, сприяння їй у досягненні властивого звичайній людині способу життя.

Розглянемо декілька визначень поняття «виховна робота». Г. Коджаспірова розглядає виховну роботу як цілеспрямовану діяльність 3 організації життєдіяльності дітей, метою якої $\epsilon$ створення умов для повноцінного розвитку особистості (Коджаспирова та Каджаспиров, 2003). Виховна робота передбачає вибір форм і методів виховання дітей відповідно до поставлених виховних задач і сам процес їх реалізації (Новотворцева, 2006). Виховна робота - це професійна діяльність педагогів, спрямована на 
створення умов розвитку й саморозвитку дитини (Веракса та ін., 2014).

У зв'язку з цим зауважимо, що виховна робота з дітьми дошкільного віку в закладах спеціальної освіти є процесом складним і багатоаспектним. До того ж, виховання, на нашу думку, $\epsilon$ обов'язковою складовою освітнього процесу дітей із затримкою психічного розвитку. Незаперечним $\epsilon$ факт, що оптимізація процесу виховання дітей із затримкою психічного розвитку в закладах спеціальної освіти може бути здійснена 3 використанням відповідної моделі. 3 цією метою нами розроблено структурно-логічна модель виховання таких дітей, основними структурними елементами якої $€$ цільовий, теоретико-методологічний, змістово-процесуальний та оцінно-результативний блоки (див. рис. 1).

Цільовий блок моделі передбачає визначення мети виховання дітей із затримкою психічного розвитку в закладах спеціальної освіти, що полягає, передусім, у створенні сприятливих соціально-педагогічних умов для максимального розвитку дитини, розкриття ії здібностей і самореалізації; забезпечення почуття психологічної захищеності.

Мета виховання дітей дошкільного віку із затримкою психічного розвитку в закладах спеціальної освіти конкретизується в низці завдань, що відображають основні напрями діяльності закладу в означеній сфері, а саме:

- зміцнення фізичного та психічного здоров'я дітей, розвиток рухової активності, виховання гігієнічної культури, залучення до цінностей здорового способу життя;

- розвиток гуманістичного спрямування ставлення дітей до світу (соціального, рукотворного, природного), виховання культури спілкування, доброзичливості, емоційної чуйності, дружніх взаємини, прагнення до співпраці, взаємодії з однолітками та близькими дорослими;

- розвиток пізнавальної активності, допитливості, прагнення дітей до експериментування (з предметами, природними об'єктами) й дослідження;

- уміння вести спостереження, порівняння, аналіз, користуватися схемами, моделями й поопераційними картами, що відображають послідовність дій дитини в різних видах діяльності;

- збагачення кругозору дітей, поглиблення й диференціювання уявлення про світ;

- розвиток ініціативи й самостійності дітей у діяльності, пізнанні та спілкуванні, неухильному розширенні сфери самостійних дій, збагачення особистого суб'єктного досвіду кожної дитини; 


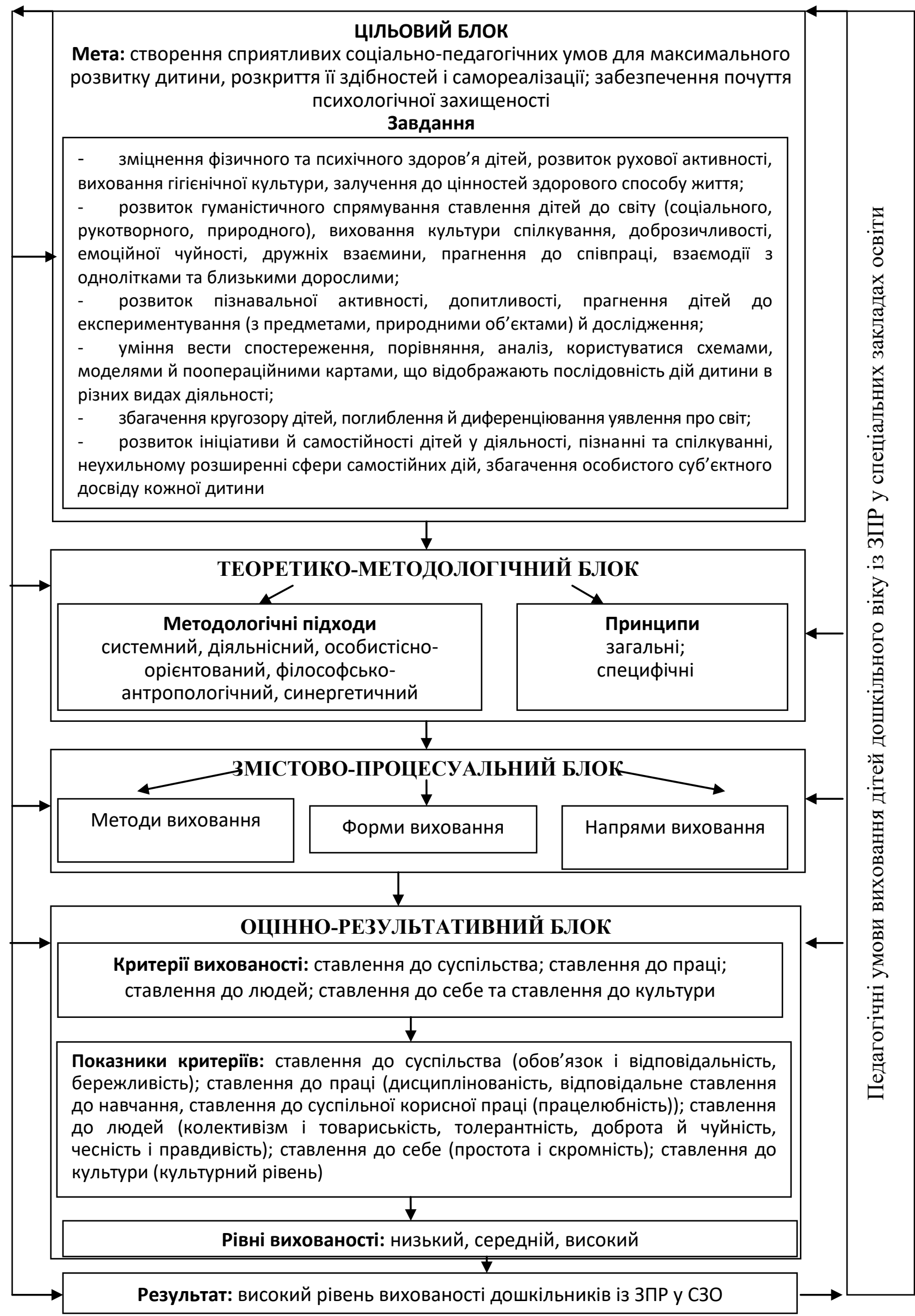

Рис. 1. Модель виховання дітей дошкільного віку із 3ПР у СЗО 
- можливість для творчого самовираження в різних видах дитячої діяльності (в іграх, театральній, музичній, комунікативній, мовній діяльності) відповідно до інтересів і схильностей дітей;

- збагачення естетичних почуттів і вражень дітей, інтересу до музики, мистецтва, художньої літератури;

- розвиток мовної культури, уміння граматично правильно, зв'язно й виразно передавати в мові власні думки, прагнення до взаєморозуміння в спілкуванні з дорослими й однолітками.

Для розв'язання цих завдань таким дітям необхідно формувати й розвивати навички соціального адаптування: самообслуговування та соціально-побутову орієнтацію, різні форми комунікації, свідоме регулювання власної поведінки в суспільстві, фізичну й соціальну мобільність. Виховна робота з дітьми із затримкою психічного розвитку зачіпає всі моменти життєдіяльності дитини в спеціальному закладі дошкільної освіти та здійснюється відповідно до робочої програми закладу, адаптованої для даної категорії дітей.

Характеризуючи теоретико-методологічний блок моделі виховання дітей дошкільного віку із затримкою психічного розвитку в спеціальних закладах освіти, зауважимо, що в сучасній науково-методичній літературі з теорії виховання пропонується використовувати в педагогічній діяльності такі методологічні підходи: системний, діяльнісний, особистісноорієнтований, філософсько-антропологічний, синергетичний та ін.

Сутність системного підходу полягає в тому, що він $є$ методологічною орієнтацією в діяльності, у якій об'єкт пізнання або перетворення розглядається як система. Використання системного підходу в процесі виховання дошкільників передбачає застосування спеціальних понять і методів, дотримання певних принципів.

Сутність виховання з точки зору діяльнісного підходу полягає в тому, що в центрі уваги знаходиться не просто діяльність, а спільна діяльність дітей і дорослих із реалізації разом вироблених цілей і завдань. Педагог не передає готові зразки моральної та духовної культури, а створює, виробляє їх разом із вихованцями. Спільний пошук цінностей, норм і законів життя в процесі діяльності і становить зміст виховного процесу, що реалізується в контексті діяльнісного підходу. Виховний процес в аспекті діяльнісного підходу виходить з необхідності проектування, конструювання та створення ситуацій виховуючої діяльності.

Під особистісно-орієнтованим підходом прийнято розуміти методологічну орієнтацію у виховній діяльності, що дозволяє за 
допомогою опори на систему взаємопов'язаних понять, ідей і способів дій забезпечувати й підтримувати процеси самопізнання, самореалізації особистості дитини, розвитку її неповторної індивідуальності.

Філософсько-антропологічний підхід відкриває можливість виховання дитини співвіднести з їі реальним життям, духовним бутям, а не підміняти "тренуванням» за допомогою внесення в реальне життя штучно створюваних ситуацій, заходів.

Синергетичний підхід - це методологічна орієнтація у виховній діяльності, що передбачає застосування сукупності ідей, понять і методів у дослідженні й управлінні відкритими нелінійними системами, що самоорганізуються, прикладом якої може виступати дитячий колектив як керована, відрита, нелінійна, система, яка самоорганізовується.

Таким чином, можна констатувати, що симбіоз вищеназваних підходів взаємодоповнює один одного та сприяє цілісному вивченню проблеми дослідження.

у межах теоретико-методологічного блоку також окреслено основні принципи, якими повинен керуватись у своїй діяльності вихователь спеціального закладу дошкільної освіти. Виховання дітей дошкільного віку із ЗПР у спеціальних закладах освіти реалізовується на основі сукупності загальних та специфічних принципів, що відображають закономірності цілісного освітнього процесу та особливості даного напряму роботи.

До перших належать: науковість, цілеспрямованість, систематичність і послідовність; взаємодія загального, особливого та індивідуального у змісті та методах виховання; свідомість, активність тощо.

До специфічних принципів віднесено:

1. Формування особистості дошкільника на основі вивчення особливостей розвитку дитини та колективу, у якому вона перебуває. У процесі виховання вихователь має спиратися на розуміння особистості дитини із затримкою психічного розвитку з урахуванням закономірностей ії психічного розвитку;

2. Поєднання роботи щодо формування соціально ціннісних особистісних якостей із корекційною роботою. Робота щодо формування особистісних якостей дошкільника із ЗПР повинна поєднуватися 3 корекційною роботою, що спрямована на виправлення тих недоліків характеру й поведінки, які виникли в результаті недосконалого й неповноцінного життєвого досвіду.

3. Орієнтація корекційно-виховної роботи на подолання соціальних і психологічних наслідків затримки психічного розвитку. у процесі 
корекційно-виховної роботи педагог повинен спрямовувати увагу не тільки на специфіку розладів у розвиткові певного дошкільника, але й на подолання соціальних і психологічних наслідків розладу.

4. Урахування специфіки процесу виховання дітей із затримкою психічного розвитку. 3 огляду на стан розвитку дитини перед нею повинні ставитись такі завдання, що $€$ доступними дошкільникам і водночас вимагають від них мобілізації всіх їхніх потенційних можливостей.

5. Визначення основним об'єктом процесу виховання формування соціальної поведінки дошкільника. У процесі виховання важливо забезпечити не лише засвоєння дитиною соціального досвіду, але й перетворення його на власні цінності, установки, орієнтації.

6. Урахування особливостей установок, що регулюють загальну спрямованість соціальної поведінки особистості. У процесі виховання дошкільників із затримкою психічного розвитку необхідно формувати в них певну систему ставлень до довкілля на основі організації практики певних стосунків у колективі, дотримуючись вимоги врахування особливостей установок, що регулюють загальну спрямованість соціальної поведінки особистості.

7. Реалізація комплексного підходу до розвитку дитини. Суттєвою вимогою до змісту виховної роботи $є$ реалізація комплексного підходу до формування та розвитку підростаючої особистості. Це зумовлює необхідність урахування цілісного характеру особистості та інтенсивного впливу на всі її сторони.

Змістово-процесуальний блок моделі виховання дітей дошкільного віку із затримкою психічного розвитку в спеціальних закладах освіти містить напрями, методи та форми виховання дітей даної категорії.

Напрями виховної роботи в спеціальних закладах дошкільної освіти класифікують за різною основою. Найбільш узагальнена класифікація включає в себе розумове, моральне, трудове, художньо-естетичне, правове виховання та фізичний розвиток.

До основних завдань морального виховання належать такі: гуманні відносини між дітьми й дорослими шляхом виконання елементарних правил життя, дбайливого ставлення до оточуючих та близьких людей, доброзичливості та чуйності; формування культури поведінки та працьовитості; формування патріотичних почуттів.

У дитячому садку трудове виховання полягає в ознайомленні дітей із працею дорослих, у залученні дітей до доступної їм трудової діяльності. Програмою для дошкільників із затримкою психічного розвитку виділені 
чотири види трудової діяльності: самообслуговування, господарськопобутова праця, праця в природі й ручна праця.

Фізичний розвиток дошкільників із ЗПР спрямований на вдосконалення функцій організму дитини, що формується, повноцінний розвиток основних рухів, різноманітних рухових навичок, удосконалення тонкої ручної моторики. Метою фізичного розвитку $є$ формування в дітей основ здорового способу життя.

Художньо-естетичне виховання передбачає: розвиток передумов ціннісно-смислового сприйняття й розуміння світу природи, творів мистецтва; становлення естетичного ставлення до навколишнього світу; формування елементарних уявлень про види мистецтва; сприйняття музики, художньої літератури, фольклору; стимулювання співпереживання персонажам художніх творів; реалізацію самостійної творчої діяльності дітей.

Правове виховання дошкільників із ЗПР у спеціальних закладах освіти передбачає: формування знань дітей про свої права та обов'язки; оцінку власної поведінки й поведінки інших людей з точки зору норм права; оперування правовими знаннями у своїй поведінці й реалізація правової поведінки в різних видах діяльності; сформованість якостей самоконтролю, самооцінки результатів діяльності; уміння дотримуватися заборони й виконувати обов'язки.

Методи виховної роботи з дітьми із ЗПР мають свою специфіку:

- оскільки дітям із ЗПР властива низька ступінь стійкості уваги, то необхідно спеціально організовувати й направляти увагу дітей; їм корисні вправи, які розвивають усі форми уваги;

- такі діти потребують великої кількості проб для того, щоб освоїти спосіб діяльності, тому необхідно дати дитині можливість діяти в одних і тих самих умовах;

- оскільки складні інструкції їм не доступні, необхідно дробити завдання на короткі відрізки та пред'являти їх дитині поетапно, формулюючи завдання чітко й конкретно;

- з огляду на те, що високий ступінь виснаження дітей із ЗПР може привести до стомлення або ж до зайвого порушення, небажано продовжувати діяльність після настання стомлення.

Найбільш доступними й ефективними для дітей дошкільного віку із ЗПР вважаються практично-дієві методи виховання: привчання, вправа, проблемні ситуації, ігри, ручна праця, образотворча й художня діяльність. Ці методи рекомендується поєднувати з різними інформаційними методами 
(бесіда, дитяча художня література, енциклопедії, екскурсії, приклади з оточуючого життя, у тому числі особистий приклад дорослого та ін.).

Виховна робота в спеціальних закладах освіти з дошкільниками із ЗПР здійснюється через такі форми, як: безпосередня освітня діяльність, безпосередня діяльність у режимних моментах, ігри, самостійна діяльність дітей (художня, трудова, рухова, дослідницька, продуктивна тощо), індивідуальна діяльність, екскурсії, проектна діяльність та ін.

Оцінно-результативний блок моделі виховання дітей дошкільного віку із ЗПР охоплює критерії вихованості, відповідні показники, рівні.

Принагідно зазначимо, що під вихованістю в педагогіці розуміють комплексну властивість особистості, яка характеризується наявністю та ступенем сформованості соціально цінних якостей і властивостей, що відображають усебічність її розвитку (Мойсеюк, 2001).

Серед основних критеріїв вихованості дошкільників визначено такі: ставлення до суспільства; ставлення до праці; ставлення до людей; ставлення до себе та ставлення до культури.

Відповідно, до показників критерію ставлення до суспільства віднесено: обов'язок і відповідальність, бережливість; показники критерію ставлення до праці включають дисциплінованість, відповідальне ставлення до навчання, ставлення до суспільної корисної праці (працелюбність); критерій ставлення до людей характеризуються такими показниками, як колективізм і товариськість, толерантність, доброта й чуйність, чесність і правдивість; до критерію ставлення до себе належить показник простота і скромність; останній критерій ставлення до культури визначається показником культурного рівня (рис. 2).

На основі аналізу науково-педагогічної літератури визначено рівні вихованості дітей дошкільного віку із ЗПР: високий, середній, низький.

Високий рівень вихованості - наявність стійкої та позитивної самостійності в діяльності й поведінці поряд із проявом активної громадської, громадянської позиції.

Середній рівень вихованості - властиві самостійність, прояви самореалізації та самоорганізації, хоча громадська позиція ще не проявляється.

Низький рівень вихованості - видається слабким, ще нестійким досвідом позитивної поведінки, що регулюється в основному вимогами старших та іншими зовнішніми стимулами й збудниками, при цьому самоорганізація й саморегуляція ситуативні. 


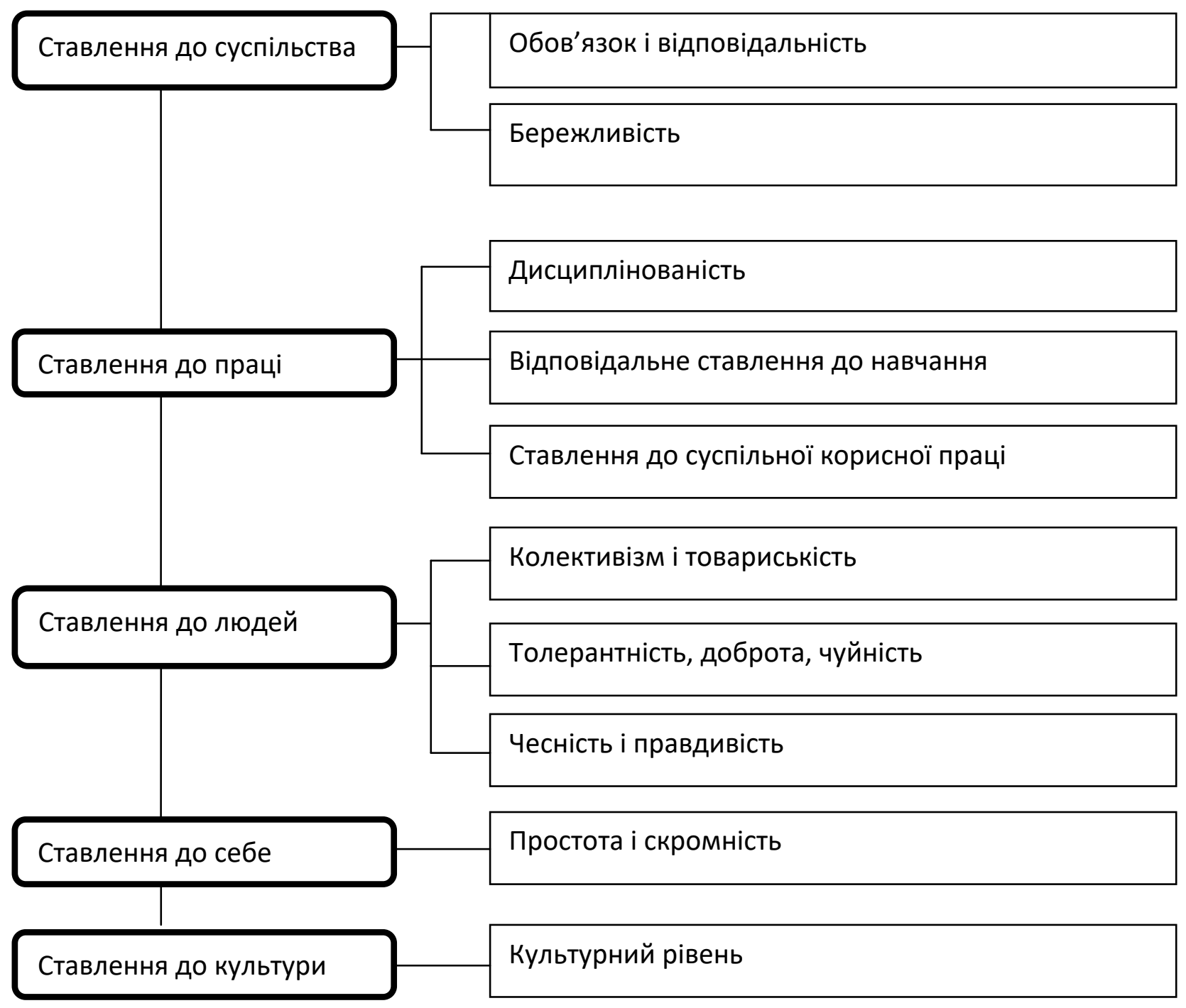

Рис. 2. Критерії та показники визначення рівня вихованості дітей дошкільного віку із ЗПР

До того ж, вважаємо за необхідне зазначити, що спеціальний освітній процес для дітей дошкільного віку із ЗПР повинен протікати в спеціальних освітніх умовах, які передбачають: освітнє середовище (комплекс умов, які забезпечують розвиток дітей у дошкільній організації: взаємодія учасників педагогічного процесу, розвивальне предметно просторове середовище (частина освітнього середовища, що являє собою спеціально-організований простір, матеріали, обладнання для розвитку дітей дошкільного віку відповідно до їх психолого-педагогічних характеристик), зміст дошкільної освіти); організаційне забезпечення (нормативно-правове забезпечення; організація різних форм навчання в спеціальних закладах дошкільної освіти; фінансові умови, інформаційне забезпечення); матеріально-технічне забезпечення (навчальнометодичний комплект, обладнання, оснащення відповідно до вікових та індивідуальних особливостей дітей, санітарно-епідеміологічних вимог, 
вимог пожежної безпеки); програмно-методичне забезпечення (навчальні плани та програми, методичні посібники, дидактичні матеріали); психолого-педагогічне забезпечення (повага дорослих до людської гідності дітей, формування й підтримка їх позитивної самооцінки, впевненості у власних можливостях і здібностях; використання у виховно-освітній діяльності форм і методів роботи з дітьми, які відповідають їх віковим та індивідуальним особливостям; побудова освітньої діяльності на основі взаємодії дорослих із дітьми та орієнтованої на інтереси й можливості кожної дитини); кадрове забезпечення (посадовий склад і кількість працівників, необхідних для реалізації виховної роботи з урахуванням характеристик дітей із ЗПР; відповідність кваліфікаційним характеристикам кваліфікацій педагогічних працівників).

Таким чином, виховна робота $є$ обов'язковою складовою освітнього процесу в дошкільній освітній організації. Цей вид педагогічної діяльності використовується для створення середовища, необхідного для всебічного розвитку дитини.

Висновки та перспективи подальших наукових розвідок. Отже, розроблена модель виховання дітей дошкільного віку із ЗПР у спеціальних закладах освіти включає реалізацію послідовно структурованих компонентів, змістове наповнення яких уточнює інформаційний образ процесу, що моделюється. Запропонована модель покликана забезпечити безперервність процесу виховання дошкільників із ЗПР у спеціальних закладах освіти.

Проведене дослідження показало, що проблема дослідження процесу виховання дітей дошкільного віку із ЗПР у спеціальних закладах освіти вимагає подальшого наукового пошуку. Становить інтерес вивчення провідних тенденцій виховання дітей із ЗПР у зарубіжних країнах.

\section{ЛITEPATУРА}

Вержиховська, О. М., Рудзевич, І. Л. (2016). Теорія і методика виховання дітей в спеціальній школі. Кам'янець-Подільський (Verzhikhovska, O. M., Rudzevнch, I. L. (2016). Theory and methodology of upbringing children in special schools. KamyanetsPodilsky).

Коджаспирова, Г. М., Каджаспиров, А. Ю. (2003). Педагогический словарь. М.: Академия (Kodzaspirova, Н. M., Kadzhaspirov, A. Yu. (2003). Pedagogical dictionary. M.: Academy).

Мойсеюк, Н. Є. (2001). Педагогіка. К.: Видавничий центр «Академія» (Moiseiuk, N. Ye. (2001). Pedagogy. K.: Publishing center "Academy").

Назарова, Н. М. (2009). Специальная педагогика: история развития научного знания и подготовка педагогических кадров. М.: «Спутник+» (Nazarova, N. М. (2009). Special pedagogy: history of development of scientific knowledge and training of teachers. M.: "Sputnik+"). 
Новотворцева, Н. В. (2006). Коррекционная педагогика и специальная психология. Словарь. СПб: Kаро (Novotovtseva, N. V. (2006). Correctional pedagogy and special psychology. Vocabulary. SPb: Caro).

Oт рождения до школы. Примерная общеобразовательная программа дошкольного образования (пилотный вариант) (2014). Н. Е. Веракса, Т. С. Комарова, М. А. Васильева (ред.). М.: Мозаика синтез (From birth to school. Sample preschool general education program (Pilot Version) (2014). N. E. Veraksa, T. S. Komarova, M. A. Vasilieva (Eds.). M.: Mosaic synthesis).

Петровский, А. В., Ярошевский, М. Г. (1996). История и теория психологии. Ростов-наДону: Феникс (Petrovsky, А. V., Yaroshevskii, M. G. (1996). History and theory of psychology. Rostov-on-Don: Phoenix).

\section{PEЗЮME}

Чистякова Ирина. Структурно-логическая модель воспитаня детей дошкольного возраста с задержкой психического развития в специальных учреждениях образования.

В статье представлена разработанная автором модель воспитания детей дошкольного возраста с задержкой психического развития в спечиальных учебных заведениях, которая включает реализацию последовательно структурированных компонентов (целевой, теоретико-методологический, содержательно-процессуальный и оченочно-результативный блоки), содержательное наполнение которых уточняет информационный образ прочесса, моделируемой системы. Предложенная модель призвана обеспечить непрерывность прочесса воспитания дошкольников с задержкой психического развития в специальных учебных заведениях. Доказано, что воспитательная работа с детьми дошкольного возраста с задержкой психического развития является обязательной составляющей образовательного процесса в специальном учебном заведении. Этот вид педагогической деятельности используется для создания среды, необходимой для всестороннего развития ребенка.

Ключевые слова: воспитание, воспитанность, дети дошкольного возраста, задержка психического развития, специальное учреждение образования, модель воспитания.

\section{SUMMARY}

Chystiakova Iryna. Structural-logical model of upbringing of preschool children with special educational needs in special education institutions.

The article presents the model of preschool education of children with mental retardation in special education institutions developed by the author, which includes implementation of consistently structured components (target, theoretical-methodological, content-procedural and evaluative-resultative units), the content of which clarifies information image of the process that is being modeled. The proposed model aims to ensure the continuity of the process of education of preschool children with mental retardation in special education institutions. It is proved that educational work with preschool children is a compulsory component of the educational process in the special education institution.

It is emphasized that special educational process for preschool children with mental retardation should take place in special educational conditions, which include: educational environment (set of conditions that ensure development of children in the preschool education institution: interaction of participants in the pedagogical process, developmental environment (part of the educational environment, which is a specially organized space, materials, equipment for the development of preschool children in accordance with their psychological and pedagogical characteristics), content of preschool education); organizational support (regulatory and legal support; organization of various forms of 
education in special institutions of preschool education; financial conditions, information support); material-technical support (educational-methodological provision, facilities, equipment in accordance with the age and individual characteristics of children, sanitary and epidemiological requirements, fire safety requirements); program-methodological support (curricula, manuals, didactic materials); psychological-pedagogical support (respect of adults for the human dignity of children, formation and maintenance of their positive self-esteem, confidence in their own abilities; use in the educational and upbringing activity of forms and methods of work with children that correspond to their age and individual characteristics; construction of educational activity based on interaction of an adult with children and focused on each child's interests and capabilities); staffing (the number of employees required to carry out educational work, taking into account the characteristics of children with mental retardation; compliance with qualification characteristics of teaching staff).

Key words: upbringing, preschool children, mental retardation, special education institution, model of upbringing. 